\title{
Utilization of Natural and Syntethic Cytokinins Towards Dragon's Blood Germination (Daemonorops didymophylla)
}

\author{
Revis Asra ${ }^{1}$, Rainiyati ${ }^{2}$, Ririn Ananda Samarlina ${ }^{3}$ \\ \{revisasra@unja.ac.id\} \\ Biology department, Faculty of Science and Technology University of Jambi ${ }^{1,2}$, Faculty of \\ Agriculture,University of Jambi, Jambi, Indonesia ${ }^{3}$
}

\begin{abstract}
Dragon'ss blood (Daemonorops didymophylla)is one of local plants in Jambi Province that has commercial value. However, the existence of this plant is rare due to lack of cultivation by local community because of long period of germination of dragon's blood seeds ( 8 months - 1 year). This researches aimed to discover the effect of given natural cyokinins (coconut milk) and synthetic (atonic) towards dragon's blood germination. Results shows that given synthetic cytokinins (atonic) at $1,5 \%$ with soaking period for 48 hours and natural cytokinins (coconut milk) at $75 \%$ at 48 hours soaking period able to stimulate fastest germination resulting only two days while soaking period towards dragon'ss blood haveno influence towards germination. The highest germination found on $1 \%$ atonic concentration and $75 \%$ concentration of coconut milk.
\end{abstract}

Keywords: Atonic, coconut milk, concentration, dragon's blood, germination and soaking period

\section{Introduction}

Dragon's blood (Daemonorops didymophylla) is one of local plants in Jambi Province that has a economy value. Dragon's blood is one of rattan palms. Generally most frequent part used from rattan is the stem, however, different with dragon's blood palm, resin is the part used resulted from its fruit. Dragon's blood resin can be used for medicine for some illness such as diarrhea, bleeding, anti tumor, as well as anti microbe. In addition, its resin also used as natural dyes (Gupta et al., 2007).

Dragon's blood resin has become source of income of Jambi citizens that live around forest and AnakDalam tribe. Based on survey about dragon's blood resin atlocal level at 20092012 is Rp. 60.000,-/kg, and since 2014 dragon's blood resin able to reaches Rp. 100.000.

Dragon's blood resin were exported into some countries. The demand of dragon's blood resin in global market were stable with higher consumer involving China, Hongkong dan Singapura. Based on data from RRC that this country requires 400 tons of dragon's blood resin every year and Indonesia only capable to export less than 27 tons per year (Arifin, 2009). Based on BPS dragon's blood palm production in Jambi decreased. Last production at 1995 reaches 15 tons after 1995-2010 dragon's blood palm production were not recorded.

Asra (2013) found four kinds of dragon's blood in Jambi forest. They were Daemonorops maculata J. Dransf., Daemonorops draconcella Becc., Daemonorops propinqua Becc. and Daemonorops draco (Willd.) Blume. Asra (2014) conduct a genetic diversity to dragon's 
blood palm (D. draco) in Jambi and Riau Province both forest in Bukit Tiga Puluh National Park and forest outside National Park and found that the highest genetic diversity found in Jambi Province therefore dragon's blood palm in Jambi Province is a potential source of germplasm.

Daemonorops didymophylla is one of dragon's blood that can produce high quality red resin (Heyne, 1987). In Tebo district (Jambi Province) local name of D. didymophylla is kelukup. According to Sulasme et al. (2012) in Jebak Village (Batanghari District, Jambi), indigenous people (Orang Rimba or Anak Dalam Tribe) called this plant as rotan kelemunting or mengkarung. This species does not depend on the season and always bear fruit throughout the year.

Dragon's blood population in Jambi province occurs a drastically decline. There are few factors cause this condition such as forest logging both legal and illegal, forest conversion for rubber and oil palm plantation, forest fire as well as lack of interest to cultivate by local community lead to a declining in producing of dragon's plant resin. This condition caused by long period of dragon's blood germination ( 8 months -1 year) and fruiting at age (5 years).

Another effort to accelerate germination of dragon's blood by giving cytokinins hormone. Cytokininis hormone able to postpone dormancy period and stimulate embryo growth. As a result, seed will be faster to germinate. Cytokinins hormone including both natural and synthetic. Therefore this research aimed to reach best concentration and soaking period to stimulate dragon's blood germination.

\section{Methods}

\subsection{Time and location}

This research was conducted from July to September 2018. Samples were collected in Secondary forest in Tebo regency, Jambi Province While speed and seeds viability were conducted in Integrity Laboratory, University of Jambi.

\subsection{Materials}

Dragon's blood seeds (Daemonorops didymophylla), synthetic sytokinin hormone (atonic) natural cytokinin (coconut milk). While materials used is micro pipette, camera, test tube, wrapper and plastic box.

\subsection{Germination test}

Peel and pulp as well as dirt were cleaned up, seeds must be soaked using clean water for 1 - 2 hours and then peel off and rinsed for few times until clean. The next following step is stored in shady and dry place.

\subsection{Treatment cytokinins hormone}

Cytokinins hormone were arranged in varied concentration by adding sterile water. Synthetic cytokinins (atonic) concentration including $0 \% ; 0,5 \% ; 1 \%$ and $1,5 \%$ while for natural cytokinins (coconut milk) $0 \% ; 25 \% ; 50 \% ; 75 \%$ and $100 \%$. The soaking were every 0 
hour, 12 hours, 24 hours, and 36 hours. In addition especially for natural cytokinins (coconut milk) after soaked 12 hours have to replaced with new one. Soaked seeds in cytokinins solvents were rinsed using clean water and soaked with fungicide (dithane) solvents for five minutes.

\subsection{Seeds germination}

Soaked seeds in cytokinins solvents were entered to white plastics and tied using a wrapper and observed to obtain time for seeds to germinate as well as germination potency.

\subsection{Data analysis}

Data obtained then analyzed using ANOVA.

\section{Results and Discussion}

\subsection{Time of seeds emerged}

Germination is a growth and development process of embryo. Dormancy is one of the factors that caused seed to postpone germination. Effort can be done to accelerate germination and seeds growth by facilitating the entry of water and oxygen to the embryo by destructing the impermeability of seeds coat by mechanical treatments towards the seeds. Therefore, before soaking using natural and synthetic cytokinins, seeds of dragon's blood were scarified first. As a result from scarification process of dragon's blood coat is increasing the permeability towards gases and water and able to trigger activation of some enzymes in seeds for overhaul process of food reserves (catabolism). According to Child (1984) instead of destructing the impermea-bility of seeds coat, giving growth regulator able to accelerate germination.

In addition giving cytokinine hormone also able to stop dormancy period from dragon's blood seeds (Daemonorops didymophylla). Rachmawati et al. (2017) reported that atonic also provide enough phenolic compound and absorbed by seeds to enhance the metabolism. While coconut milk contain high amount of auxcyn to stimulate cells division in seeds.

Based on ANOVA using two factors involving soaking period and cytokinin concentration (atonic and coconut milk) shows that all treatment shows a significant changes (F > Fcrit, Pvalue < Fcrit). Soaking using cytokinins hormone able to penetrate peel seeds and accelerate germination.

Least Significance Different test at 5\% shows every treatment shows significant changes towards dragon's blood germination time (Table 1 and Table 2). 
Table 1.Interaction of synthetic cytokins (atonic) concentration and soaking period (days)

\begin{tabular}{lllll}
\hline Synthetic Cytoninins & \multicolumn{4}{l}{ Soaking period (hours) } \\
\cline { 2 - 5 } Concentration (\%) & 0 & 24 & 36 & 48 \\
0 & $6 \mathrm{~h}$ & $5,67 \mathrm{gh}$ & $4,67 \mathrm{ef}$ & $3,67 \mathrm{~cd}$ \\
0,5 & $6,3 \mathrm{~h}$ & $5 \mathrm{fg}$ & $4 \mathrm{de}$ & $3 \mathrm{bc}$ \\
1 & $5,67 \mathrm{gh}$ & $4,67 \mathrm{ef}$ & $3 \mathrm{bc}$ & $2,3 \mathrm{ab}$ \\
1,5 & $4,3 \mathrm{def}$ & $3,67 \mathrm{~cd}$ & $2,67 \mathrm{ab}$ & $2 \mathrm{a}$ \\
\hline
\end{tabular}

Note: rates at column follow by different letter (not same) show significant changes at LSD test significance level $5 \%$

Utilization of synthetic cytokinins (atonic) at 1,5\% with 48 hours soaking period shows a significant changes towards another treatments (best concentration) because thus concentration able to trigger endogen auxcyn to enhance cells osmosis pressure, protein synthesize, while Farida (2018) reported that soaking using atonic will facilitate milk and oxygen to penetrate the seeds in germination process.

Atonic is growth regulator which contain phenolic compound, natrium, brown, dissolve in milk as well as has a distinctive aroma. Atonic components consisted of natrium 5nitroguaicol $(\mathrm{C} 7 \mathrm{H} 6 \mathrm{NO} 4 \mathrm{Na})$, natrium ortonitrofenol $(\mathrm{C} 6 \mathrm{H} 4 \mathrm{NO} 3 \mathrm{Na})$, natrium para-nitrofenol $(\mathrm{C} 6 \mathrm{H} 4 \mathrm{NO} 3 \mathrm{Na})$ and natrium 2.4 - dinitrofenol $(\mathrm{C} 6 \mathrm{H} 3 \mathrm{~N} 2 \mathrm{O} 5 \mathrm{Na})$. Those components affecting germination time to broke dormancy period. In addition, atonic also enhance protoplasm flow rate, stimulate root and shoot growth, flowering, prevent loss of flowering and fruiting, pollen, enhance fertilization, and improve fruit quality (Asahi, 1979). Saputra et al. (2017) reported that Atonic contain both cytokinin and auxcyn that fasten food reserves degradation in seeds to become milk soluble components. Those components will be transmitted and used to formed new cells at embryo in forming protoplasm for germination. This condition in line with Sunarlim et al. (2012) report that atonic is one of growth regulator from liquid auxcyn group that able to accelerate root formation, enhance the absorption of nutrients and encourage vegetative growth as well as stimulating flowering phase.

In addition, giving synthetic cytokinins also reinforce nutrients transmission into plant cells. The smooth process of transporting food reserves digested by seeds of germinating plants is directly proportional to the speed of seed germination.

Giving higher atonic concentration were affecting germination time to become faster. However, too high atonic concentration cause enzyme activity for cell respiratory were obstructed. As a result, respiration will be reduced and cause declining milk contents in plant tissue. While Suhaila et al. (2013) using atonic for $8 \mathrm{cc} / 1$ were inhibit the growth of Cylindroladium sp.

Soaking period also related to amount of water that able to penetrate into seeds (Hartoyo 2015). This conditions were related to given atomic concentration (mixing between water and atonic). Water is a crucial factor for germination. Water penetrates into seeds will hydrolyze starch as a source of food reserves and energy in germination. Lack of water will cause metabolism disorder. 
Table 2.Interaction of natural cytokinin (coconut milk) and soaking period (days)

\begin{tabular}{lllll}
\hline $\begin{array}{l}\text { Natural Cytokinin } \\
\text { Concentration } \\
(\%)\end{array}$ & \multicolumn{4}{l}{ Soaking period } \\
\cline { 2 - 5 } 0 & 0 hour & 24 hours & 36 hours & 48 hours \\
25 & $6^{\mathrm{h}}$ & $5,67^{\mathrm{gh}}$ & $4,67^{\mathrm{ef}}$ & $3,67^{\mathrm{cd}}$ \\
& $5,67^{\mathrm{gh}}$ & $5,3^{\mathrm{fgh}}$ & $4,3 \mathrm{de}$ & $3,3 \mathrm{bc}$ \\
50 & $5,67^{\mathrm{gh}}$ & $5^{\mathrm{efg}}$ & $3,67 \mathrm{~cd}$ & $3^{\mathrm{bc}}$ \\
75 & $5^{\mathrm{efg}}$ & $4,3^{\mathrm{de}}$ & $3^{\mathrm{bc}}$ & $2^{\mathrm{a}}$ \\
100 & $5,67^{\mathrm{gh}}$ & $4,67^{\mathrm{ef}}$ & $3,3^{\mathrm{bc}}$ & $2,6^{\mathrm{ab}}$ \\
\hline
\end{tabular}

Note: rates at column follow by different letter (not same) show significant changes at LSD test significance level $5 \%$

Utilization of natural cytokinins (coconut milk) at $75 \%$ with 48 hours soaking period shows a significant changes towards another treatments (best treatment) because those concentration that exist in growth regulator and coconut milk able to stimulate germination. In line with this Fathonah et al. (2011) conduct research about soaking period towards palm seeds for 24 hours using varied coconut milk concentration $0 \%, 25 \%, 50 \%, 75 \%$ and $100 \%$. Best result shows at $75 \%$.

Growth regulator and nutrients from coconut milk are extremely required for growth and development process. In addition, coconut milk contain organic compound such as vitamins (B and C), hormones (auxcyn, cytokinins, gibberellic acid, protein, carbohydrates, $\mathrm{Ca}$ and $\mathrm{P}$ ) (Purdyaningsih, 2013).

According to Halimursyadah et al. (2015) coconut milk extract facilitate imbibition process from seeds and stimulate germination. Adding coconut milk (organic compounds) that contain cytokinin and auxcyn to accelerate cells division.

\subsection{Seedling viability}

Seeding viability shown by amount of normal seed emerged at certain time and condition and \pm 30 determine in seedling viability. Based on ANOVA cytokinins concentration (atonic and coconut milk) is significantly different towards dragon's blood seedling viability ( $\mathrm{F}>\mathrm{Fcrit}$, Pvalue $<$ Fcrit) while soaking period did not show any significant changes towards seedling viability $(\mathrm{F}<$ Fcrit). According to Sunarnilam et al. (2012) shows that soaking period using atonic did not affect seedling viability to Citrullus vulgaris Sumpena (2006) shows that seeds viability of cucumber seeds did not affected by soakingperiod contarary given atonic concentration affecting seeds viability. 
Table 3.Interaction of synthetic cyotokinis (atonic) concentration and soaking period towards rates of seeds viability of dragon's blood seeds

\begin{tabular}{lllll}
\hline $\begin{array}{l}\text { Atonic Concentration } \\
(\%)\end{array}$ & \multicolumn{4}{l}{ Soaking Period (hours) } \\
\cline { 2 - 5 } 0 & 0 & 24 & 36 & 48 \\
0,5 & $41,67 \%^{\mathrm{a}}$ & $50 \%^{\mathrm{b}}$ & $58,3 \%^{\mathrm{c}}$ & $66,67 \% \mathrm{~d}$ \\
1 & $75 \%^{\mathrm{e}}$ & $83,3 \%^{\mathrm{f}}$ & $83,3 \%^{\mathrm{f}}$ & $91,67 \%^{\mathrm{g}}$ \\
1,5 & $83,3 \%^{\mathrm{f}}$ & $91,67 \%^{\mathrm{g}}$ & $91,67 \%^{\mathrm{g}}$ & $91,67 \%^{\mathrm{g}}$ \\
\hline
\end{tabular}

Note: rates at column follow by different letter (not same) show significant changes at LSD test significance level 5\%

Based on data, it can be seen clearly that the highest rates seeds viability resulted from treatment at atonic 1\%. In line with this Hartman et al. (1990) reported that atonic can be effective at certain concentration. Based on data it can be seen that the highest rates seedlings viability found in atonic at $1 \%$ concentration. Seedling viability treated using atonic is higher compared to water (control).

Low concentration did not effective in stimulating germination while too high concentration able to obstruct seeds viability. This condition cause dragon's blood palm viability increase along with given atonic concentration and stopped at $1,5 \%$ this concentration did not effective in stimulating germination.

Table 4.Interaction of natural cytokines (coconut milk) concentration and soaking period towards rates of seeds viability of dragon's blood seeds.

\begin{tabular}{lllll}
\hline Coconut & \multicolumn{4}{l}{ Soaking period (hours) } \\
\cline { 2 - 5 } $\begin{array}{l}\text { Concentration } \\
(\%)\end{array}$ & 0 & 24 & 36 & 48 \\
0 & & & & \\
25 & $67^{\mathrm{a}}$ &, & $3^{\mathrm{c}}$ & $.67^{\mathrm{d}}$ \\
50 & $67^{\mathrm{a}}$ & $3^{\mathrm{c}}$ & $3^{\mathrm{f}}$ & $.67^{\mathrm{g}}$ \\
75 & $3^{\mathrm{f}}$ & $3^{\mathrm{f}}$ & $3^{\mathrm{f}}$ \\
100 & $67^{\mathrm{d}}$ & & $3^{\mathrm{f}}$ & $.67^{\mathrm{f}}$ \\
\hline
\end{tabular}

Note: rates at column follow by different letter (not same) show significant changes at LSD test significance level $5 \%$

Statistic analysis for soaking period using coconut milk shows that soaking period did not show significant changes towards seeding viability. However, there is a significant changes towards seeds that soaked using coconut milk compared to control. Coconut milk contain some hormones involving cytokinin $(5,8 \mathrm{mg} / \mathrm{l})$, auxcyn $(0,07 \mathrm{mg} / \mathrm{l})$, gibberelic acid and another components that able stimulating germination and growth in plant (Morel, 1974). Cytokinin and auxcyn play a great role in cell division and differentiation certain tissue in forming root and shoot development while gibberellic acid beneficial in germination acceleration

The highest rates seedling viability shown at concentration $25 \%$ and $75 \%$ with soaking period 48 hours. This condition in line with Fathonah et al. (2011) using varied concentration $(0 \%, 25 \%, 50 \%, 75 \%$ and $100 \%)$ towards palm seeds and the highest viability is $96,25 \%$. Tampubolon (2016) reported that soaking seeds using coconut milk 100\% did not effective 
because without combination of coconut milk and milk will cause concentrate solution. As a consequence, absorption of cytokinin were reduced both in and outside of cells resulting less active cell division.

Giving coconut milk were based on concentration because the higher given concentration will cause mortality (lethal) in seeds. While according to Sujarwati et al. (2011) cytokinins will actively in cells division at concentration 40-80\%. Application of coconut milk with appropriate concentration will affect the germination from dragon's blood seeds, otherwise both too high and low concentration of organic hormone or growth regulator will not affected the growth and development.

The success of growth hormone application such as cytokinin determine by some factors such as appropriate concentration, methods, growth regulator, appropriate timing, kinds of growth regulator because each growth regulator has its own specifications towards plant growth and development (Santosa, 2013).

\section{Conclusions}

Dragon's blood seeds (Daemonorops didymophylla) that soaked using atonic at $1,5 \%$ for 48 hours using coconut milk at $75 \%$ shows the fastest germination time at second day. The most effecting concentration found in atonic $1 \%$ and coconut milk $75 \%$ towards seeds viability while soaking period did not show significant changes.

\section{References}

[1]Arifin, W. 2009. Jernang: Tanaman Konservasi bernilai Ekonomis Tinggi dan Prospeknya di Provinsi Jambi. http://wein-arifin.blogspot.com/2009/01/ jernang-tanaman-konservasi (diakses tanggal 27 Januari 2018).

[2]Asahi Chemical. 1979. Atonik: A New Type of Plant Stimulant. Japan: Asahi Chemical Mfg. Co. Ltd.

[3]Asra, R. 2013. Diversity Dragon's Blood Palm (Daemonorops spp.) di Hutan Sekunder Jambi. Prosiding Seminar Nasional Biodiversitas dan Ekologi Tropika (BIOETI I).

[4]Asra, R. Syamsuardi, Mansyurdin, Joko Ridho Witono (2014). Genetic Diversity of the Dragon's Blood Rattan Daemonorops draco (Palmae) Using ISSR Markers, BIODIVERSITAS. Journal of Biological Diversity, Volume 15, Number 2

[5Child, R. 1984. Coconuts.Inggris: Longmans, Green and CO ltd.

[6]Fathonah, Johani dan Herlina. 2011. Penggunaan Air Kelapa untuk Meningkatkan Perkecambahan dan Pertumbuhan Palem Putri (Veitchia Merillii). Jurnal SAGU. Laboratorium Botan iFakultas MIPA Biolagi, Universitas Riau. 10(1): 24-28.

[7]Farida. 2018. Pengaruh Lama Perendaman dalam Larutan Kimia Terhadap Sifat Dormansi Biji Aren (Arengna pinnata Wurmn Merr). Jurnal Pertanian Terpadu. 6(1): 21-29.

[8]Gupta, D., Bleakley, B., and Gupta, R.K., 2007. Dragon'ss's blood: Botany, chemistry and therapeutic uses. Journal of Ethnopharmacology, 115: 361-380.

[9]Halimursyadah, Jumini dan Muthiah. 2015. Penggunaan Organic Priming dan Periode Inkubasi Untuk Invigorisasi Benih Cabai Merah ( Capsicum annum L.) Kadalurasa pada Stadia Perkecambahan. Banda Aceh: Universitas Syiah Kuala.

[10]Hartmann, H. T., D. E. Kester dan F. T. Davis-Jr. 1990. Plant Propagation: Principles and Practices. USA: Prentice-Hall International Inc.

[11]Hartoyo, Eko. 2015. Pengaruh Lama Perendaman Benih dengan Triakonatol dan Berbagai Konsentrasi Zat Atonik terhadap Pertumbuhan dan Hasil Tanaman Wortel (Daucus carrota L.). Jurnal Agrinnec'a. 15(1): 1-12. 
[12]Heyne K. 1987. De Nuttige Planten van Indonesie. Badan Litbang Departemen Kehutanan, Jakarta, Indonesia.

[13]Morel GM. 1974. Cloral multiplication of orchid. In C.L. Withner (ed.). The Orchid Scientific Studies. New York: Wiley-Interscience Publication. John Wiley and Sons. [14]Motaz, A.: Start programming using Object Pascal. Vol. 2, pp. 10-11. Legally Free Computer Books, US (2013)

[14]Purdyaningsih, Eko. 2013. Kajian Pengaruh Pemberian Air Kelapa dan Urine Sapi Terhadap Pertumbuhan Stek Nilam. Balai besar Perbenihan dan Proteksi Tanaman Perkebunan.

[15]Rachmawati, D. L., M. Roviq dan T. Islami. 2017. Komposisi Atonik dan Air Kelapa pada Pertumbuhan Bud Chips Tebu (Saccharum officinarum L.). Jurnal Produksi Tanaman. 5(5): 851-859..

[16]Santoso, B. B. 2013. Zat Pengatur Tumbuh Dalam Pertumbuhan dan Perkembangan Tanaman. Universitas Sam Ratulangi.

[17]Saputra, Bayu., T. Kurniastuti dan P. Puspitorini. 2017. Pengaruh Kombinasi Sklarifikasi dan Perendaman Auksin Terhadap Viabilitas Benih dan Petumbuhan Awal Semangka Non Biji (Citrus vulgaris Schard L). Jurnal Viabel Pertanian. 11(2): 9-17.

[18]Suhaila, S. Zahrah dan Sulhaswardi. 2013. Perbandingan Campuran Meda Tumbuh dan Berbagai Konsentrasi Atonik Untuk Pertanaman Bibit (Eucalyptus pellita). Jurnal Dinamika Pertanian. 18(3): 225-236.

[19]Sulasmi, I. K., Nisyawati. Purwanto, Y. Fatimah, S. 2012. The population of Jernang rattan (Daemonorops draco) in Jebak Village, Batanghari District, Jambi Province, Indonesia. BIODIVERSITAS. Vol. 13 (4): 2085-4722

[20]Sujarwati, S Fathonah, E Johani dan Herlina. 2011. Penggunaan Air Kelapa untuk Meningkatkan Perkecambahan biji Palem Putri (Veitchia merilli) Sagu. Agricultural science and thecnology journal. 10 (1): 24-29.

[21]Sunarlim,N., S.I. Zam dan J. Purwanto. 2012. Pelukaan Benih Dan Perendaman Dengan Atonik Pada Perkecambahan Benih Dan Pertumbuhan Tanaman Semangka Non Biji (Citrullus vulgaris Schard L.) Jurnal Agroteknologi. 2(2): 29-32.

[22]Sumpena, U. 2006. Respon hasil, viabilitas dan vigor benih Mentimun (Cucumis sativus L.) Kultivar Saturnus Terhadap Perlakuan Atonik. Jurnal Agrivigor. 5(3): 287 - 292.

[23]Tampubolon, Antoni., M. Mardiansyah dan T. Arlita. 2016. Perendaman Benih Saga (Adenathera pavonina L). Dengan Berbagai Konsentrasi Air Kelapa Untuk Meningkatkan Kuliatas Kecambah. Jurnal Online Mahasiswa Fakultas Pertanian Universitas Riau. 3(1): 1-6. 